TITLE:

\title{
Effectiveness of cyclic irrigation in reducing suspended solids load from a paddy-field district
}

\section{AUTHOR(S):}

Hama, Takehide; Nakamura, Kimihito; Kawashima, Shigeto

\section{CITATION:}

Hama, Takehide ...[et al]. Effectiveness of cyclic irrigation in reducing suspended solids load from a paddy-field district. Agricultural Water Management 2010, 97(3): 483-489

\section{ISSUE DATE:}

2010-03

URL:

http://hdl.handle.net/2433/91252

\section{RIGHT:}

c 2009 Elsevier B.V. All rights reserved.; This is not the published version. Please cite only the published version.; この論文は出版社版でありませ ん。引用の際には出版社版をご確認ご利用ください。 
Effectiveness of cyclic irrigation in reducing suspended solids load from a paddy-field district

Takehide Hama ${ }^{1}$, Kimihito Nakamura ${ }^{1}$, Shigeto Kawashima ${ }^{1}$

${ }^{1}$ Graduate School of Agriculture, Kyoto University. Kitashirakawa Oiwake-cho, Sakyo-ku, Kyoto, 606-8502, Japan.

Corresponding author: Takehide Hama, Graduate School of Agriculture, Kyoto University. Kitashirakawa Oiwake-cho, Sakyo-ku, Kyoto, 606-8502, Japan.

E-mail: hama@kais.kyoto-u.ac.jp, Phone: +81-75-753-6155, Fax: +81-75-753-6476 
Hama et al.

\section{Abstract}

3

4 The reduction of suspended solids, nutrients, and organic matter loads in drainage water from

5 paddy fields is an important issue for water quality management in closed water areas in

6 Japan. We evaluated the ability of cyclic irrigation to reduce the suspended solids load from

7 paddy fields. In 2006 and 2007, we investigated water and mass balances during the irrigation

8 period in a low-lying paddy-field district neighboring Lake Biwa, which is the largest lake in

9 Japan. We confirmed that cyclic irrigation reduced effluent loads during the puddling season.

10 With cyclic irrigation, $118 \mathrm{~kg} \mathrm{ha}^{-1}$ of suspended solids was returned to the paddy fields in

112006 and $199 \mathrm{~kg} \mathrm{ha}^{-1}$ in 2007. The effect of cyclic irrigation on the net suspended solids load can be represented by three ratios: the concentration ratio, which represents the ratio of the suspended solids concentration in drainage water to that in lake water; the cyclic irrigation ratio, which represents the ratio of the volume of reused water to that of irrigation water in cyclic irrigation; and the surplus irrigation water ratio, which represents the ratio of the volume of surplus irrigation water to that of irrigation water. The cyclic irrigation ratio and the surplus irrigation water ratio interact to determine the effect of cyclic irrigation on the net suspended solids load. Simultaneously increasing the cyclic irrigation ratio and decreasing the surplus irrigation water ratio will maximize the purification effect on drainage water from paddy fields.

\section{Keywords}

Cyclic irrigation, water reuse, suspended solids, paddy fields. 
Hama et al.

\section{1. Introduction}

3

4 The reduction of pollutants such as suspended solids, nutrients, and organic matter from non-point sources is an important issue for water quality management in closed water areas. In particular, pollutant loads from paddy-field districts, which use large amounts of water, must be reduced.

8 Cyclic irrigation is considered an effective water management practice for reducing 9 pollutant loads from paddy-field districts. Cyclic irrigation was originally developed as a method for saving water in low-lying paddy fields (Kudo et al., 1995; Takeda et al., 1997) or terraced paddy fields (Tabuchi, 1986; Nakamura et al., 1998), where a stable and sufficient water source was not available. In cyclic irrigation systems, drainage water is partially reused as irrigation water, so that the downstream effluent volume is decreased by the amount of reused water. This approach is expected to decrease pollutant loads, both because less water leaves the fields and because at least some of the pollutants in the water will be returned to the fields.

17 Several researchers have studied the reduction effect of cyclic irrigation. Kubota et al. (1979) reported that cyclic irrigation with a recycling ratio (the ratio of reused water to drainage water) of $34 \%$ reduced nitrogen loads by $29 \%$ and phosphorus loads by $37 \%$. In addition, cyclic irrigation may increase the hydraulic retention time of nutrients and thereby enhance water purification in a paddy-field district (Feng et al., 2004, 2005; Takeda and Fukushima, 2006). It has been also reported that the ability of cyclic irrigation to reduce loads of nutrients is directly proportional to the amount of reused water (Kaneki et al., 2003) and the recycling ratio (Hasegawa et al., 1982; Shiratani et al., 2004; Hitomi et al., 2006). There is, however, a low upper limit to the potential recycling ratio in many paddy-field districts that 
capture industrial or domestic wastewater from upstream areas, because irrigation water must have a large fresh water component to reduce the risks posed by pollutants including pathogens and heavy metals (Kaneki, 1989; Zulu et al., 1996). Little is known about the ability of cyclic irrigation conducted with high recycling ratios to reduce loads from paddy-field districts. Furthermore, there have been few studies of this reduction effect as a function of the suspended solids load, even though suspended solids can cause various deleterious impacts (Bilotta and Brazier, 2008).

We have been investigating a paddy-field district neighboring Lake Biwa, the largest lake in Japan, since 2004. We previously reported characteristics of the mass balances of nitrogen and phosphorus in the district, and evaluated the ability of cyclic irrigation to reduce nutrient loads in effluent (Hama et al, 2007, 2008). In the present paper, we present the results for 2006 and 2007 and discuss the ability of cyclic irrigation to reduce suspended solids load.

\section{Materials and methods}

\subsection{Study site}

The study site is located in Konohama District $\left(35^{\circ} 05^{\prime} \mathrm{N}, 135^{\circ} 56^{\prime} \mathrm{E}\right)$, on the southeastern side of Lake Biwa in Shiga Prefecture. Lake Biwa is the largest lake in Japan and the most important water resource for the Kinki region, which includes Osaka and Kyoto (Fig. 1). Konohama District covers $1.48 \mathrm{~km}^{2}$, of which more than $90 \%$ is used as paddy fields. About one-third of the paddy fields are cultivated under a system of crop rotation of wheat and soybeans.

24 There is no inflow of industrial or domestic wastewater from outside the study area into the drainage and irrigation canals, because the paddy-field district does not have upstream 
watersheds. The amount and flow pattern of drainage and irrigation water in the district is strongly influenced by water management practices in the paddy fields. The drainage and irrigation canals are separated (Fig. 1b). In the study area, the drainage system is mainly composed of 14 lateral drainage canals that supply a main drainage canal, which passes through the district from north to south. The length, width, and depth of the main drainage canal are about $1.5 \mathrm{~km}, 2-4 \mathrm{~m}$, and $0.5-2 \mathrm{~m}$, respectively. Rainfall runoff from the paddy fields and surplus irrigation water from the irrigation canals flow into the main drainage canal via the lateral drainage canals. There is a floodgate at each end of the main drainage canal. Outflow of drainage water from the paddy-field district is controlled by operation of the floodgates.

Pumps at the northern and southern ends of the main drainage canal have capacities of 0.7 and $0.1 \mathrm{~m}^{3} \mathrm{~s}^{-1}$, respectively. The northern pump station has two water inlets that connect to the lake and the main drainage canal, respectively, whereas the southern pump station has a single water inlet that only connects to the main drainage canal. Pumped water is delivered to outlets (points I1 - I7 in Fig. 1b) through underground pipelines, and is supplied to the paddy fields through the several irrigation canals. The maximum amount of irrigation water depends solely on the capacity of the pumps, because there is no other source of water to the irrigation canals. Rainfall is not included in the irrigation water. The pumps operate for about $12 \mathrm{~h}$ per day, from 6:00 am to 6:00 pm.

Two types of irrigation have been practiced in the district: lake water irrigation and cyclic irrigation. In lake water irrigation, irrigation water is pumped from Lake Biwa into the irrigation canals by the northern pump. The lake water irrigation is a conventional irrigation system that is widely used in low-lying paddy-field districts along the lake shore. Under cyclic irrigation, most irrigation water is pumped from the main drainage canal, which functions as a retention pond. The infrastructure for cyclic irrigation (pump stations, main 
1

2

3

4

8

drainage canal, and floodgates) in the district was developed between 1998 and 2005, and cyclic irrigation has been practiced since 2004. The increased cost of practicing of cyclic irrigation in the district is met by direct agri-environmental payments from the government of Shiga Prefecture.

The irrigation period is about 130 days, including a mid-summer drainage season of about 10 days (Table 1). Cyclic irrigation is conducted from the beginning of the irrigation period to the mid-summer drainage season (the cyclic irrigation period), then lake water irrigation is conducted to the end of the irrigation period (the lake water irrigation period). The cyclic irrigation and lake water irrigation periods are both about 60 days long. Soil puddling is accompanied by tillage of the paddy field to soften the soil before rice seedlings are transplanted at the beginning of the irrigation period. The suspended solids concentration in the drainage canals water is especially high during the soil puddling season (Kaneki, 2003; Somura et al., 2009).

\subsection{Water quality and hydrological data}

Since 2004, we have undertaken weekly water quality measurement within the district during the irrigation period. In addition, we have investigated two paddy plots in the district. We sampled water at the outlet for pumped irrigation water (I1), at both ends of the main drainage canal (St.1 and St.2), and at the inner lake (St.3) (Fig. 1b).

In the laboratory, we analyzed suspended solids according to the method in Japanese Industrial Standard (JIS) K0102. For this paper, we defined suspended solids as suspended matter with particle sizes ranging from $1 \mu \mathrm{m}$ to $2 \mathrm{~mm}$. We placed turbidimeters (Compact-CLW, JFE Alec Co., Ltd.) at both ends of the main drainage canal, set to a measurement interval of $20 \mathrm{~min}$. Turbidimeter measurements were calibrated to convert 
1 turbidity readings to suspended solids content: calibration was performed by developing a relationship between field-measured turbidity and laboratory-measured suspended solids concentration of drainage water samples taken concurrently with turbidmeter readings. velocity, relative humidity, and solar radiation were measured at the southern pump station. The flow rate of drainage water was measured using 2150 Area Velocity Flow Module flow meters (Teledyne Isco Inc.) installed at both ends of the main drainage canal. Evapotranspiration was estimated by the Penman method (Penman, 1948; Miura and Okuno, 1993) using data collected at the southern pump station. We estimated the volume of pumped water by multiplying the operating duration of the pumps by their capacity. We did not measure subsurface percolation from the district, but assumed it to be negligible because the district is low-lying and close to the lake, and the groundwater level is high. We measured the irrigation and runoff water flow rates delivered to and drained from each paddy plot using a Parshall flume set at the inlet and a triangular weir set at the outlet. We estimated the volumes of irrigation and runoff water to and from the paddy field by averaging the measured values for the paddy plots.

\section{Results}

\subsection{Water balances}

Table 2 shows the water balances in the paddy field during the irrigation periods. The large amount of runoff water during the 2007 mid-summer drainage season was due to rainfall and the temporary removal of shuttering boards at the outlets of the paddy plots during the irrigation season. The difference between total inflow and total outflow (which equals the sum 
1 of stored water, leakage from paddy levees, and percolation) was $771 \mathrm{~mm}$ over 130 days in

$2 \quad 2006$ and $577 \mathrm{~mm}$ over 127 days in 2007. From these results, we calculated that water loss

3 from the paddy fields by leakage and percolation was less than $6 \mathrm{~mm} \mathrm{~d}^{-1}$ during the irrigation

4 period.

5 The amount of surplus irrigation water can be estimated as the volume of pumped water

6 minus the volume of irrigation water used in the paddy fields (evapotranspiration plus

7 percolation plus leakage). Total amounts of pumped water in the irrigation periods were 1737 mm in 2006 and $1681 \mathrm{~mm}$ in 2007, and the amounts of surplus irrigation water were therefore

$91226 \mathrm{~mm}$ in 2006 and $1112 \mathrm{~mm}$ in 2007. We defined the surplus irrigation water ratio $\left(\alpha_{\mathrm{SW}}\right)$ as the ratio of surplus irrigation water to irrigation water. The overall surplus irrigation water ratio in the district in the irrigation periods was 70\% in 2006 and 66\% in 2007.

We measured daily variations in rainfall and drainage water from the district through the floodgates (Fig. 3). Drainage water was not released during the cyclic irrigation periods, except during rainfall events, whereas during the lake water irrigation periods drainage water of more than $10 \mathrm{~mm} \mathrm{~d}^{-1}$ was released even on sunny days. The amount of drainage water discharged from the district on sunny days during the lake water irrigation periods nearly equaled the amount of surplus irrigation water, suggesting that cyclic irrigation reduced the outflow of surplus irrigation water from the district.

Table 3 shows the water balances in the district during the irrigation periods. Although the amounts of pumped water during the cyclic irrigation periods (1111 mm in 2006 and $962 \mathrm{~mm}$ in 2007) were larger than those during the lake water irrigation periods (626 mm in 2006 and $719 \mathrm{~mm}$ in 2007), the amounts of lake water intake during the cyclic irrigation periods were less than those during the lake water irrigation periods, because pumped water was mainly supplied by the reuse of drainage water during cyclic irrigation. The smaller amounts of drainage water discharged from the district during the cyclic irrigation periods were also due 
1 to the reuse of drainage water. The amounts of reused water (pumped water minus lake water intake) during the cyclic irrigation periods were $977 \mathrm{~mm}$ in 2006 and $788 \mathrm{~mm}$ in 2007.

3 The characteristics of cyclic irrigation can be described by two different parameters (Kudo 4 et al., 1995). One parameter is the ratio of reused water to pumped water (reused water plus 5 lake water intake). Here, we refer to this parameter $\left(\alpha_{\mathrm{CI}}\right)$ as the cyclic irrigation ratio. The 6 other is the ratio of reused water to potential drainage water (reused water plus district 7 drainage water discharged from the district), which is referred to as the recycling ratio and has 8 often been used in previous studies (e.g., Kubota et al., 1979; Hasegawa et al., 1982; Hitomi 9 et al., 2006). The recycling ratio depends more on drainage water than on reused water; in other words, the recycling ratio is affected more by water management in the paddy field and by weather conditions than is the cyclic irrigation ratio. For example, an increase in irrigation water into the paddy fields leads to a decrease in drainage water discharged from the district and results in a larger recycling ratio. Alternatively, in the case of cyclic irrigation after a rainfall event, increases in drainage water discharged from the district decrease the recycling ratio. Because of these problems with the recycling ratio, we have only analyzed and discussed the cyclic irrigation ratio in the rest of this paper.

The mean cyclic irrigation ratio of the weekly measurements during the cyclic irrigation periods was 88\% in 2006 and $82 \%$ in 2007.

\subsection{Mass balances of suspended solids}

We measured temporal variations in the drainage water suspended solids concentration at the southern end of the main drainage canal during the irrigation periods (Fig. 4). The variation trends were similar in 2006 and 2007. The suspended solids concentration was high during the puddling season (from late April to mid-May) and during heavy rainfall events; the 
suspended solids concentration was more than $100 \mathrm{mg} \mathrm{L}^{-1}$ at its peak during the puddling season. The suspended solids concentration on sunny days during the cyclic irrigation periods after the puddling season was about $20 \mathrm{mg} \mathrm{L}^{-1}$ and was higher than about $10 \mathrm{mg} \mathrm{L}^{-1}$ on sunny days during the lake water irrigation periods. The suspended solids concentration in irrigation water during the suspended solids periods nearly equaled suspended solids concentration in the drainage water because the cyclic irrigation ratios during the cyclic irrigation periods were high and the dilution volumes from the lake water were small.

Table 4 shows mass balances for suspended solids load in the district during the irrigation periods. We calculated the suspended solids loads by multiplying the suspended solids concentrations by the flow volumes. The outflow of suspended solids loads during the cyclic irrigation periods were less than those during the lake water irrigation periods, even though the cyclic irrigation periods included the puddling seasons, when the suspended solids load in runoff water from the paddy plots was very high. Clearly, the amount of suspended solids load discharged from the district was reduced during the cyclic irrigation periods.

Another effect of cyclic irrigation is to return suspended solids to the paddy fields along with the reused water. The return of suspended solids to the paddy field during cyclic irrigation, estimated from the product of the suspended solids concentration and the amount of irrigation water, was $118 \mathrm{~kg} \mathrm{ha}^{-1}$ in 2006 and $199 \mathrm{~kg} \mathrm{ha}^{-1}$ in 2007.

\section{Discussion}

In this section, we discuss the effect of cyclic irrigation on the net suspended solids load during the normal irrigation period, which represents the irrigation period after the puddling season. The net suspended solids load associated with irrigation is defined as the outflow of suspended solids load minus the inflow of suspended solids load (e.g., Takeda et al., 1997). 
1 The net load indicates whether there is an increase or decrease in suspended solids load

2 discharged from the district compared to that in the irrigation water entering the district. A

3 positive value of the net suspended solids load during cyclic irrigation indicates that cyclic

4 irrigation is increasing suspended solids load.

5 The suspended solids load is the product of the suspended solids concentration and the

6 water flow volume, as described above. Thus, the net suspended solids load, $L_{\text {net }}\left(\mathrm{kg} \mathrm{ha}^{-1} \mathrm{~d}^{-1}\right)$,

7 is given by the following equation:

$8 \quad L_{\text {net }}=C_{\text {out }} Q_{\text {out }}-C_{\text {in }} Q_{\text {in }}$

where $C$ is the suspended solids concentration $\left(\mathrm{mg} \mathrm{L}^{-1}\right), Q$ is the water flow volume $\left(\mathrm{mm} \mathrm{d}^{-1}\right)$, and the subscripts out and in refer to outflow from and inflow into the district, respectively. In this case, $C_{\text {out }}$ is the suspended solids concentration in the drainage water, $Q_{\text {out }}$ is the amount of drainage water discharged from the district per day, $C_{\text {in }}$ is the suspended solids concentration in the lake water, and $Q_{\text {in }}$ is the amount of lake water intake per day. We estimated the relationship between the cyclic irrigation ratio and each variable, as described in the following sections.

\subsection{Relationship between the cyclic irrigation ratio and the suspended solids concentration}

$$
\text { We plotted the relationship between the cyclic irrigation ratio }\left(\alpha_{\mathrm{CI}}\right) \text { and } C_{\text {out }} \text { during the }
$$
normal irrigation periods (Fig. 5). $C_{\text {out }}$ may be proportional to $\alpha_{\mathrm{CI}}$ because more pumping of drainage water leads to higher water flow and more erosion of bottom sediments in the main drainage canal. The distribution of the fields under rotation crops (i.e., crops other than paddy rice) may also influence $C_{\text {out }}$. The fields were distributed around the northern and southern of the district in 2006 and around the center of the district in 2007. We hypothesize that more of 
the suspended solids in rainfall runoff from the field under crop rotation settled out in the main drainage canal in 2007 than in 2006 because the distance from the rotation crop areas to the floodgates was shorter in 2006. Accordingly, the cyclic irrigation may have led to higher $C_{\text {out }}$ in 2007 than in 2006.

On the other hand, it is clear that $C_{\text {in }}$ is essentially independent of $\alpha_{\mathrm{CI}}$ because the impact of drainage water discharged from the district on suspended solids concentration in the lake water would be negligible. $C_{\text {in }}$ ranged from 0 to $10 \mathrm{mg} \mathrm{L}^{-1}$ during the irrigation period. The mean value of $C_{\text {in }}$ was $4.5 \mathrm{mg} \mathrm{L}^{-1}$.

\subsection{Relationship between the cyclic irrigation ratio and the flow volume}

$$
\text { Consider the water flow during the cyclic irrigation period on a sunny day (Fig. 6). } Q_{\mathrm{p}}
$$
represents the volume of pumped water and is about $20 \mathrm{~mm} \mathrm{~d}^{-1}$. On sunny days, $Q_{\mathrm{p}}$ is the only driving force for water flow in the district. We have assumed that water in the paddy field on a sunny day is mainly lost by evapotranspiration and that the amount of leakage water is negligible. In addition, runoff water occurs mainly during rainfall events. Thus, runoff and leakage (water flows from the paddy field into the main drainage canal via the lateral drainage canals) are not depicted in Fig. 6.

Drainage water discharged from the district may potentially equal to the surplus irrigation water, $\alpha_{\mathrm{sw}} Q_{\mathrm{p}}$. Cyclic irrigation reduces the outflow of this potential drainage water due to reuse, $\alpha_{C I} Q_{\mathrm{p}}$. Therefore, $Q_{\text {out }}$ (actual drainage water) is written:

$$
Q_{\text {out }}=\left(\alpha_{\mathrm{SW}}-\alpha_{\mathrm{CI}}\right) Q_{\mathrm{p}}
$$

The model of water flow illustrated in Fig. 6 does not consider temporary deficits of inflow water, which in practice are compensated for by decreases in drainage water flow in the main drainage canal. Eq. (2) means that the upper limit of $\alpha_{\mathrm{CI}}$ is $\alpha_{\mathrm{Sw}}$ when water flows out ( $Q_{\text {out }}>$ 
10 ). If $\alpha_{S W}<\alpha_{C I}$ in Eq. (2), another inflow of water from the lake must occur (negative $Q_{\text {out }}$ in

2 Fig. 6). In that case, $L_{\mathrm{net}}=-\left(1-\alpha_{\mathrm{Sw}}\right) C_{\mathrm{in}} Q_{\mathrm{in}}$; that is, under these conditions, $L_{\mathrm{net}}$ varies with

$3 \quad \alpha_{\mathrm{SW}}$ and is negative for any $\alpha_{\mathrm{CI}}$.

4 Cyclic irrigation also reduces the inflow of water (lake water intake), $Q_{\text {in }}$, due to reuse.

5 Thus, $Q_{\text {in }}$ is written as follows:

$6 \quad Q_{\text {in }}=\left(1-\alpha_{\mathrm{CI}}\right) Q_{\mathrm{p}}$

These two parameters, $\alpha_{\mathrm{CI}}$ and $\alpha_{\mathrm{Sw}}$, can be taken as a supply- (source-) and demand-

(user-) side water use parameter, respectively.

9

\subsection{The effect of cyclic irrigation as a function of the cyclic irrigation ratio}

Whether $L_{\text {net }}$ is greater or less than zero indicates whether the effect of cyclic irrigation as a function of $\alpha_{\mathrm{CI}}$ represents net contamination (cyclic irrigation increases the suspended solids load) or net purification (cyclic irrigation decreases the suspended solids load). The neutral effect, $L_{\text {net }}=0$, can be converted into the following equation by substituting the relationships between $\alpha_{\text {CI }}$ and $Q_{\text {out }}$ (Eq. (2)) and $Q_{\text {in }}$ (Eq. (3)) into Eq. (1):

The effect of cyclic irrigation on $L_{\text {net }}$ for a given $\alpha_{\mathrm{Sw}}$ value is illustrated in Fig. 7. If we replace the right side of Eq. (4) with $\beta$, then $\beta$ varies as a function of both $\alpha_{\mathrm{CI}}$ and $\alpha_{\mathrm{Sw}}$. Whether the effect of cyclic irrigation represents net contamination or net purification depends on whether the actual concentration ratio $\left(C_{\text {out }} / C_{\text {in }}\right)$ for a given $\alpha_{\mathrm{CI}}$ is above or below the $\beta$ curve. In addition, the effect of cyclic irrigation at any $\alpha_{\mathrm{CI}}$ is net purification if the concentration ratio is less than 1 , because the value of $\beta$ for any combination of $\alpha_{C I}$ and $\alpha_{\text {SW }}$ is greater than or equal to 1 .

Fig. 8 shows the measured concentration ratios during the normal irrigation periods, as well 
as five $\beta$ curves for various values of $\alpha_{\mathrm{SW}}(=0.2,0.4,0.6,0.8$, and 1.0$)$. It is clearly that the effect of cyclic irrigation at high $\alpha_{C I}$ will be net purification even if $\alpha_{S w}$ is high, whereas at low $\alpha_{\mathrm{CI}}$ the effect of cyclic irrigation may be net contamination when $\alpha_{\mathrm{Sw}}$ is greater than 0.6 . Though intermediate values of the cyclic irrigation ratio were not used in the district, Fig. 8 indicates that conducting cyclic irrigation with a moderate value of $\alpha_{C I}$ will not necessarily cause net purification if increasing $\alpha_{\mathrm{CI}}$ increases the concentration ratio. The possibility that increasing $\alpha_{\mathrm{CI}}$ increases $C_{\text {out }}$ is shown in Fig. 5. irrigation. When the value of $\alpha_{S w}$ is high, the effect of cyclic irrigation is net contamination for almost all values of $\alpha_{\mathrm{CI}}$. In contrast, the effect of cyclic irrigation is net purification for almost all value of $\alpha_{\mathrm{CI}}$ when $\alpha_{\mathrm{SW}}$ has a low value. $\alpha_{\mathrm{SW}}$ is strongly influenced by weather conditions, especially evapotranspirational demand and rainfall, and by water management practices in the paddy fields. In fact, daily $\alpha_{\mathrm{Sw}}$ ranged from 0.3 to 0.9 and was high in the spring and low in the summer in the study district.

Based on these results, two approaches can be used to produce net purification through cyclic irrigation; increasing $\alpha_{\mathrm{CI}}$ and decreasing $\alpha_{\mathrm{SW}}$. Both parameters interact to determine the net effect of cyclic irrigation. Fig. 8 suggests that improving both parameters simultaneously will reduce net suspended solids load more effectively than improving either parameter alone.

\section{Conclusions}

We confirmed that cyclic irrigation can effectively reduce the suspended solids load during the puddling season when the suspended solids concentration in drainage water is high. The return of suspended solids to the paddy fields in the irrigation district by means of cyclic irrigation totaled $118 \mathrm{~kg} \mathrm{ha}^{-1}$ in 2006 and $199 \mathrm{~kg} \mathrm{ha}^{-1}$ in 2007. 
Drainage water discharged from the district may potentially equal to the surplus irrigation water on a sunny day during the normal irrigation period. Cyclic irrigation reduces the outflow of this potential drainage water due to reuse. The effect of cyclic irrigation on the net suspended solids load can be represented by three ratios: the concentration ratio, which represents the ratio of the suspended solids concentration in drainage water to that in lake water; the cyclic irrigation ratio, which represents the ratio of the volume of reused water to that of irrigation water in cyclic irrigation; and the surplus irrigation water ratio, which represents the ratio of the volume of surplus irrigation water to that of irrigation water. Both the latter parameters interact to determine the net effect of cyclic irrigation. Simultaneously increasing the cyclic irrigation ratio and decreasing the surplus irrigation water ratio is important to maximize purification effect.

Acknowledgements

We thank Prof. Kaneki Ryoichi, University of Shiga Prefecture, for providing us with water quality data for the paddy plots. We also thank the Konohama Land Improvement District, the Konohama Agricultural Union, and the Shiga Prefecture Office for providing access to the paddy plots for investigation and for providing daily reports on water management and farming activity in the paddy fields. The research described in this paper was partly funded by a grant from the Kinki Regional Agricultural Administration Office of the Japanese Ministry of Agriculture, Forestry and Fisheries, and by a Grant-in-Aid for Scientific Research from the Japan Society for the Promotion of Science.

\section{References}


Hama et al.

1 Bilotta, G. S., Brazier, R. E., 2008. Understanding the influence of suspended solids on water

2 quality and aquatic biota. Water Res. 42, 2849-2861.

3 Feng, Y. W., Yoshinaga, I., Shiratani, E., Hitomi, T., Hasebe H., 2004. Characteristics and

4 behavior of nutrients in a paddy field area equipped with recycling irrigation system. Agric.

$5 \quad$ Water Manage. 68, 47-60.

6 Feng, Y. W., Yoshinaga, I., Shiratani, E., Hitomi, T., Hasebe H., 2005. Nutrient balance in a

$7 \quad$ paddy field with a recycling irrigation system, Water Sci. Technol. 51(3), 151-157.

8 Hama, T., Nakamura, K., Mitsuno, T., 2007. Mass balances of nitrogen and phosphorus in the

9 paddy field district implementing cyclic irrigation. Trans. JSIDRE 250, 91-97 (in Japanese

10 with English abstract).

11 Hama, T., Nakamura, K., Kawashima, S., Mitsuno, T., 2008. Effect of cyclic irrigation on

12 reduction of net effluent loadings of nitrogen and phosphorus during sunny days in

13 irrigation period after puddling season. Trans. JSIDRE 257, 11-17 (in Japanese with

14 English abstract).

Hasegawa, K., Kobayashi, M., Nakamura, M., Nakata, H., 1982. The effect of return flow irrigation on balance of water polluting material in paddy fields (1). Report of Shiga Prefecture Agricultural Center 24, 65-78.

Hitomi, T., Yoshinaga, I., Feng, Y. W., Shiratani, E., 2006. Nitrogen removal function of recycling irrigation system. Water Sci. Technol. 53(2), 101-109.

Kaneki, R., 1989. Pollutant reduction to Lake Biwa by using a cyclic irrigation system. J. JSIDRE 57(7), 39-44 (in Japanese).

Kaneki, R., Nakamura, M., Izumi, M., Himeno, Y., 2003. Water purification by lagoon and cyclic irrigation. J. JSIDRE 71(9), 31-36 (in Japanese).

Kaneki, R., 2003. Reduction of effluent nitrogen and phosphorus from paddy fields. Paddy Water Environ. 1, 133-138. 
1 Kubota, H., Tabuchi, T., Takamura, Y., Suzuki, S., 1979. Water and material (N, P) balance in

2 the paddy fields along Lake Kasumigaura. Trans. JSIDRE 84, 22-28 (in Japanese with

3 English abstract).

4 Kudo, A., Kawagoe, N, Sasanabe, S., 1995. Characteristics of water management and outflow

5 load from a paddy field in a return flow irrigation area. J. JSIDRE 63(2), 49-54 (in

6 Japanese).

7 Miura, T. Okuno, R., 1993. Detailed description of calculation of potential evapotranspiration

8 using the Penman EQUATION. Trans. JSIDRE 164, 157-163 (in Japanese with English

$9 \quad$ abstract).

10 Nakamura, Y., Manpuku, K., Koga, Y., 1998. Conservation of water environment on cyclic

11 irrigation system in the Inbanuma basin. J. JSIDRE 66(12), 37-44 (in Japanese).

Penman, H. L., 1948. Natural evaporation from open water, bare soil and grass. Proc. Roy. Soc. Lond. A, 193, 120-145.

Shiratani, E., Yoshinaga, I., Feng, Y. W., Hasebe, H., 2004. Scenario analysis for reduction of effluent load from an agricultural area by recycling the run-off water. Water Sci. Technol. 49(3), 55-62.

Somura, H., Takeda, I., Mori, Y., 2009. Influence of puddling procedures on the quality of rice paddy drainage water. Agric. Water Manage. 96, 1052-1058.

Tabuchi, T., 1986. Nitrogen outflow diagram in a small agricultural area. Trans. JSIDRE 124, 53-60 (in Japanese with English abstract).

Takeda, I., Fukushima, A., Tanaka, R., 1997. Non-point pollutant reduction in a paddy-field watershed using a cyclic irrigation system. Water Res. 31, 2685-2692.

Takeda, I., Fukushima, A., 2006. Long-term changes in pollutant load outflows and purification function in a paddy field watershed using a cyclic irrigation system. Water Res. 40, 569-578. 
1 Zulu, G., Toyota, M., Misawa, S., 1996. Characteristics of water reuse and its effects on paddy

2 irrigation system water balance and the riceland ecosystem. Agric. Water Manage. 31,

$3 \quad 269-283$.

4 


\section{Tables}

3

4 Table 1 Water management and farming activities in the paddy field.

\begin{tabular}{|c|c|c|c|}
\hline \multicolumn{2}{|c|}{ Date } & \multirow{2}{*}{ Water managemant and farming activities } & \multirow{2}{*}{ Remarks } \\
\hline 2006 & 2007 & & \\
\hline Late April & Late April & Fertilizer application & Input*: $\mathrm{N}=28 \mathrm{~kg} \mathrm{ha}^{-1}, \mathrm{P}=26 \mathrm{~kg} \mathrm{ha}^{-1}$ \\
\hline 24 April & 25 April & Start of irrigation (pumps begin operation) & The start of the irrigation period \\
\hline \multicolumn{2}{|c|}{ Late April - mid May } & Soil puddling and transplanting of rice seedling & Puddling season \\
\hline Late June & Late June & Fertilizer application & Input*: $\mathrm{N}=14 \mathrm{~kg} \mathrm{ha}^{-1}, \mathrm{P}=0 \mathrm{~kg} \mathrm{ha}^{-1}$ \\
\hline 26 June to 7 July & 24 June to 5 July & Drying of the paddy soil (temporary cessation of pumping) & Mid-summer drainage season \\
\hline Mid-July & Mid-July & Fertilizer application & Input*: $\mathrm{N}=48 \mathrm{~kg} \mathrm{ha}^{-1}, \mathrm{P}=0 \mathrm{~kg} \mathrm{ha}^{-1}$ \\
\hline 31 August & 28 August & Cessation of irrigtation (pumps cease operation) & The end of the irrigation period \\
\hline September & September & Hervesting of rice & \\
\hline
\end{tabular}

* Input of $\mathrm{N}$ and $\mathrm{P}$ were estimated from records of fertilizer application in the paddy plots. 
1 Table 2 Water balances in the paddy field during the irrigation periods. CI, cyclic irrigation;

2

LWI, lake water irrigation.

\begin{tabular}{|c|c|c|c|c|c|}
\hline \multirow{2}{*}{ Year } & \multirow{2}{*}{ Period } & \multicolumn{2}{|c|}{ Inflow (mm) } & \multicolumn{2}{|c|}{ Outflow (mm) } \\
\hline & & Rainfall & Irrigation water & Evapotranspiration & Runoff \\
\hline \multirow[t]{4}{*}{2006} & CI period (24 April to 25 June) & 277 & 275 & 212 & 72 \\
\hline & Mid-summer drainage season & 102 & 0 & 37 & 8 \\
\hline & LWI period (8 July to 31 August) & 400 & 500 & 241 & 213 \\
\hline & Total & 779 & 775 & 490 & 293 \\
\hline \multirow[t]{4}{*}{2007} & CI period (25 April to 23 June) & 281 & 356 & 273 & 138 \\
\hline & Mid-summer drainage season & 175 & 0 & 38 & 157 \\
\hline & LWI period (6 July to 28 August) & 319 & 506 & 261 & 193 \\
\hline & Total & 775 & 862 & 572 & 488 \\
\hline
\end{tabular}

4 
1 Table 3 Water balances in the district during the irrigation periods.

\begin{tabular}{|c|c|c|c|c|c|}
\hline \multirow{2}{*}{ Year } & \multirow{2}{*}{ Period } & \multicolumn{2}{|c|}{ Inflow (mm) } & \multicolumn{2}{|c|}{ Outflow (mm) } \\
\hline & & Rainfall & Lake water intake & Evapotranspiration & Drainage water \\
\hline \multirow[t]{4}{*}{2006} & CI period (24 April to 25 June) & 277 & 134 & 186 & 221 \\
\hline & Mid-summer drainage season & 102 & 0 & 29 & 71 \\
\hline & LWI period (8 July to 31 August) & 400 & 582 & 237 & 707 \\
\hline & Total & 779 & 716 & 452 & 999 \\
\hline \multirow[t]{4}{*}{2007} & CI period (25 April to 23 June) & 281 & 174 & 248 & 237 \\
\hline & Mid-summer drainage season & 175 & 0 & 31 & 94 \\
\hline & LWI period (6 July to 28 August) & 319 & 669 & 258 & 768 \\
\hline & Total & 775 & 843 & 537 & 1099 \\
\hline
\end{tabular}

3 
1 Table 4 Mass balances for the suspended solids load in the district during the irrigation

2 periods. "Inflow" refers to the suspended solids load in the lake water intake, whereas

3 "outflow" refers to the suspended solids load in the drainage water discharged from the

4 district into the lake.

\begin{tabular}{cccc}
\hline Year & Period & Inflow $\left(\mathrm{kg} \mathrm{ha}^{-1}\right)$ & Outflow $\left(\mathrm{kg} \mathrm{ha}^{-1}\right)$ \\
\hline 2006 & CI period (24 April to 25 June) & 7 & 90 \\
& Mid-summer drainage season & 0 & 35 \\
& LWI period (8 July to 31 August) & 26 & 152 \\
\cline { 2 - 4 } & Total & 33 & 277 \\
\hline 2007 & CI period (25 April to 23 June) & 28 & 80 \\
& Mid-summer drainage season & 0 & 39 \\
& LWI period (6 July to 28 August) & 30 & 183 \\
\cline { 2 - 4 } & Total & 58 & 302 \\
\hline
\end{tabular}

6 


\section{Figure captions}

3

$4 \quad$ Fig. 1. (a) Location of the study site. (b) Map of land use, irrigation and drainage canals and

5 of the water sampling points at the study site.

6

7 Fig. 2. Conceptual diagram of water flow in the district. Upper-case "P" represents a pump

8 and arrows indicate flow direction.

9

10 Fig. 3. Daily drainage water from the district, and rainfall during the irrigation periods in (a) 2006 and in (b) 2007. CI, cyclic irrigation; LWI, lake water irrigation.

Fig. 4. Temporal variation in the suspended solids concentration (SSC) in the drainage water at the southern end of the main drainage canal during the irrigation periods in (a) 2006 and in (b) 2007.

Fig. 5. Relationship between the cyclic irrigation ratio $\left(\alpha_{\mathrm{CI}}\right)$ and the suspended solids concentration in the drainage water. CI, cyclic irrigation; LWI, lake water irrigation.

Fig. 6. Conceptual diagram of water flows under cyclic irrigation: upper-case "P" represents a pump and arrows indicate the flow direction.

Fig. 7. The effect of cyclic irrigation on the net suspended solids load $\left(L_{n e t}\right)$ as a function of the cyclic irrigation ratio. 
1 Fig. 8. Measured concentration ratios in the district in 2006 and 2007. The subscript for each

$2 \beta$ value $\left(=\left[1-\alpha_{C I}\right] /\left[\alpha_{S W}-\alpha_{C I}\right]\right)$ represents the value of the surplus irrigation ratio $\left(\alpha_{S W}\right)$

3 used to calculate the $\beta$ curve.

4 
a) Location

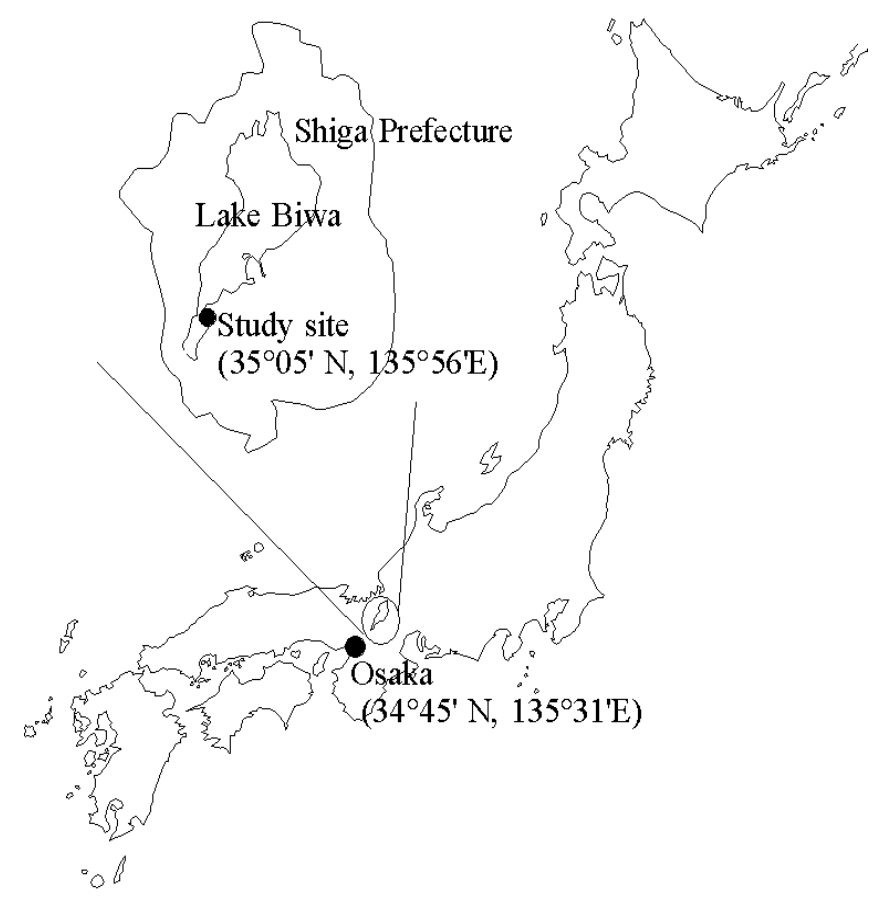

b) Map

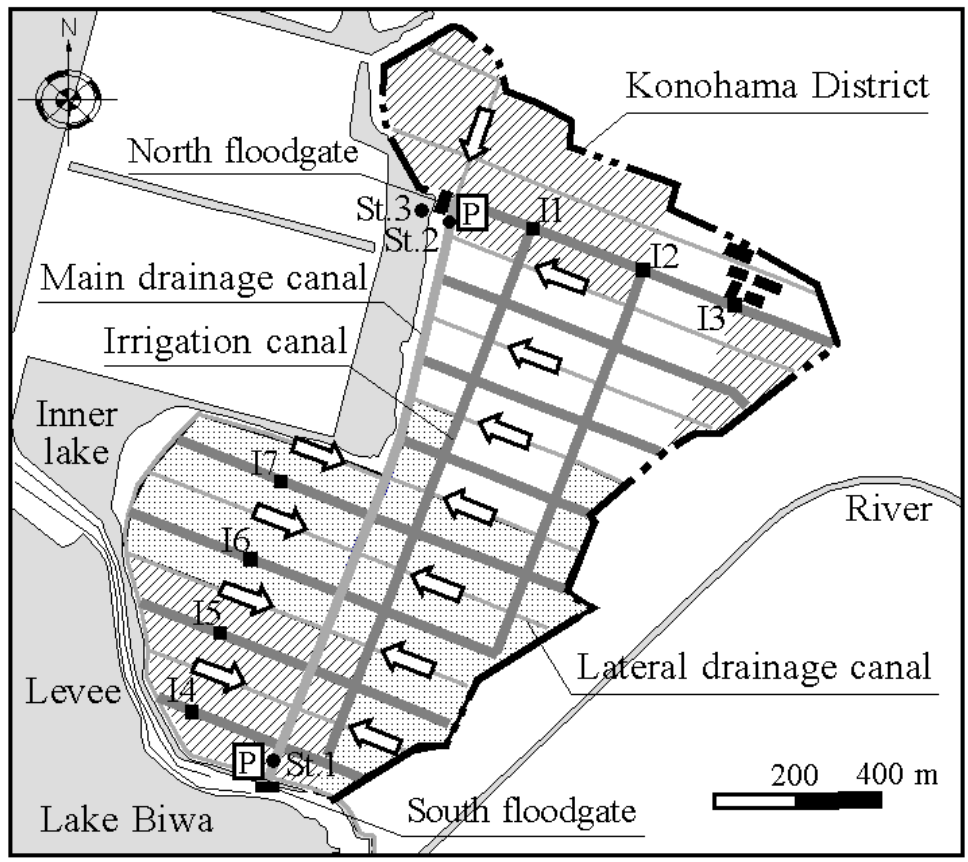

Ð Pump station Outlet of pumped-up irrigation water

- Water sampling point

VIIA Crop-rotated paddy fields in 2006

Crop-rotated paddy fields in 2007

$\hookleftarrow$ Flow direction of drainage water 
Rainfall $\downarrow$ Evapotranspiration

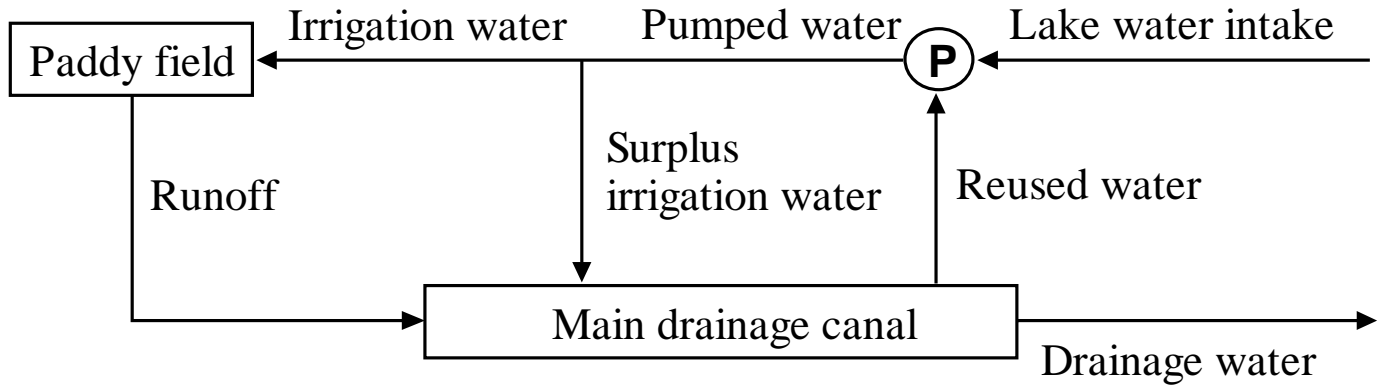



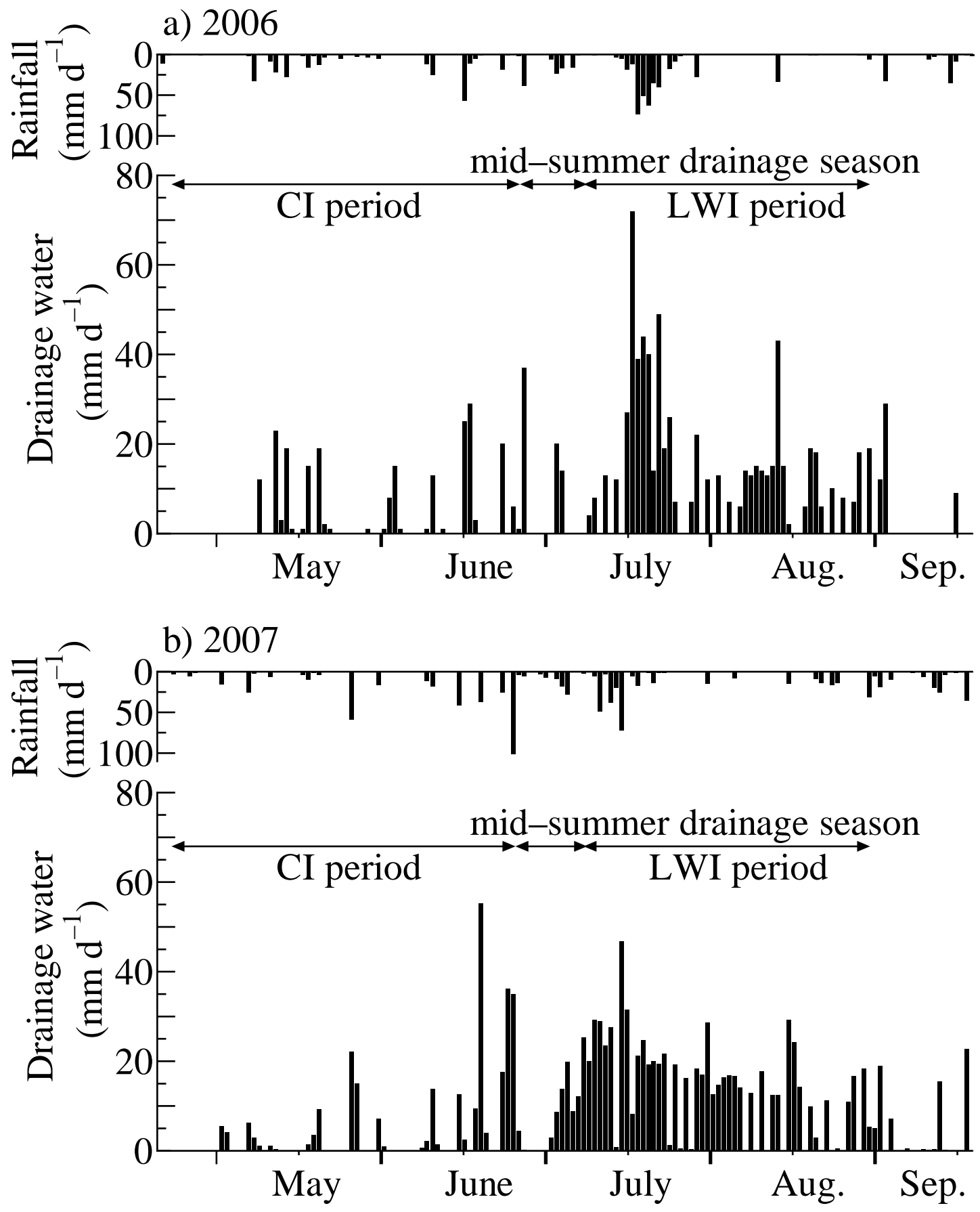

Figure 3

Hama et al. 

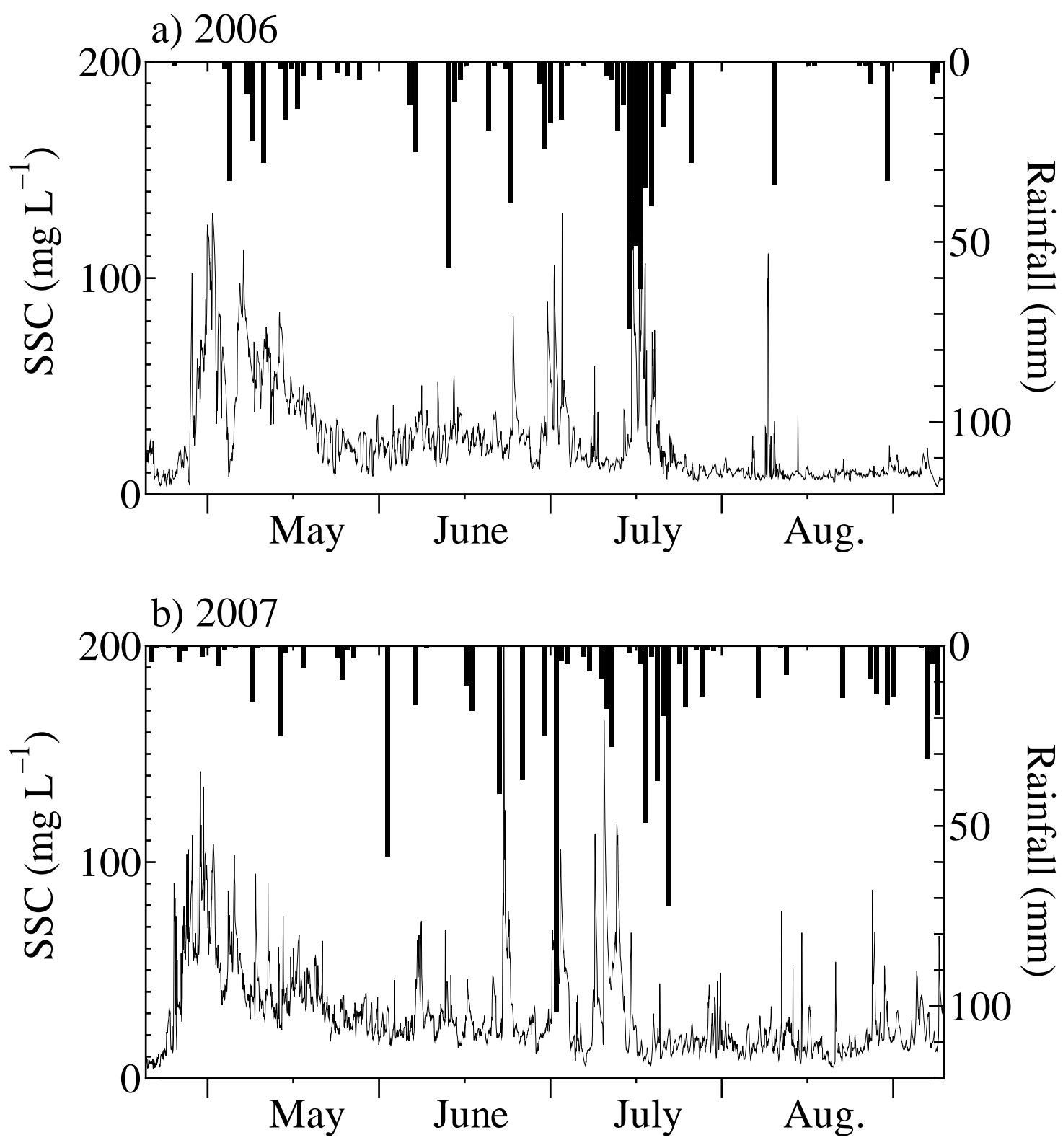

Figure 4

Hama et al. 


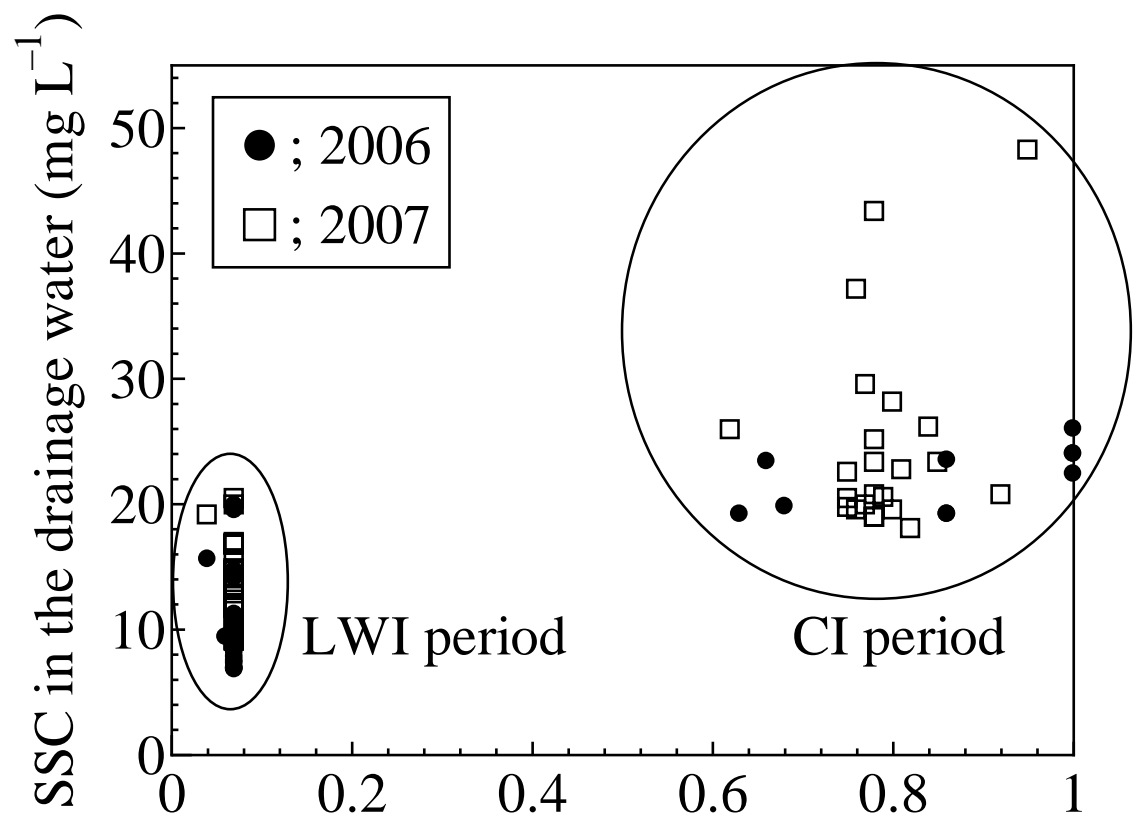

Cyclic irrigation ratio $\left(\alpha_{\mathrm{CI}}\right)$ 


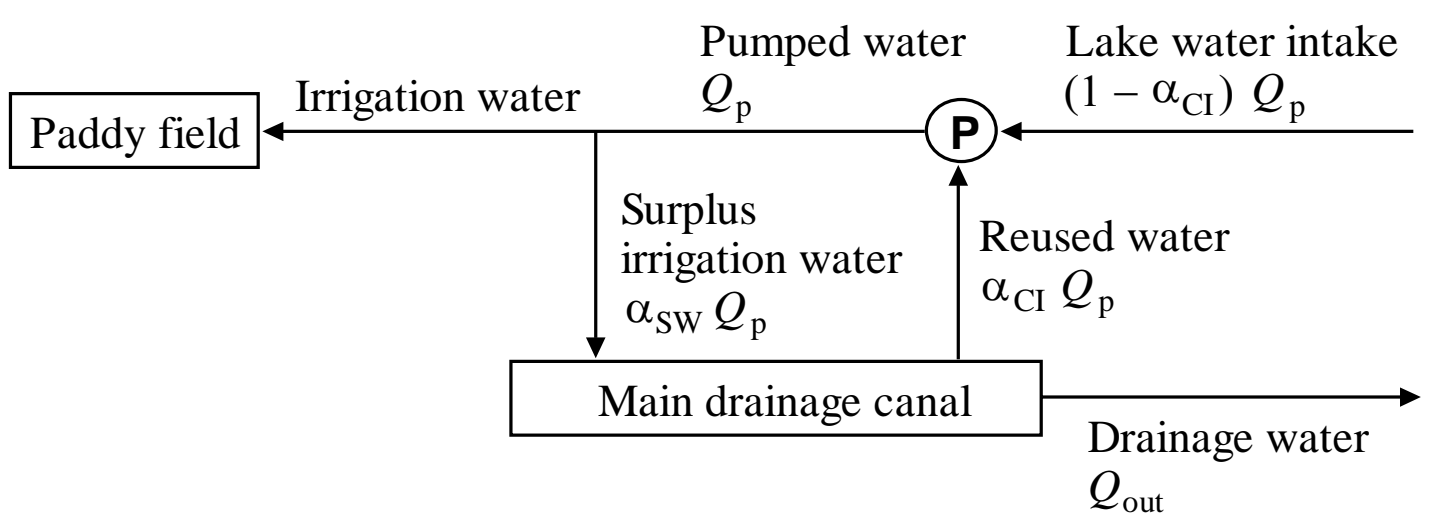




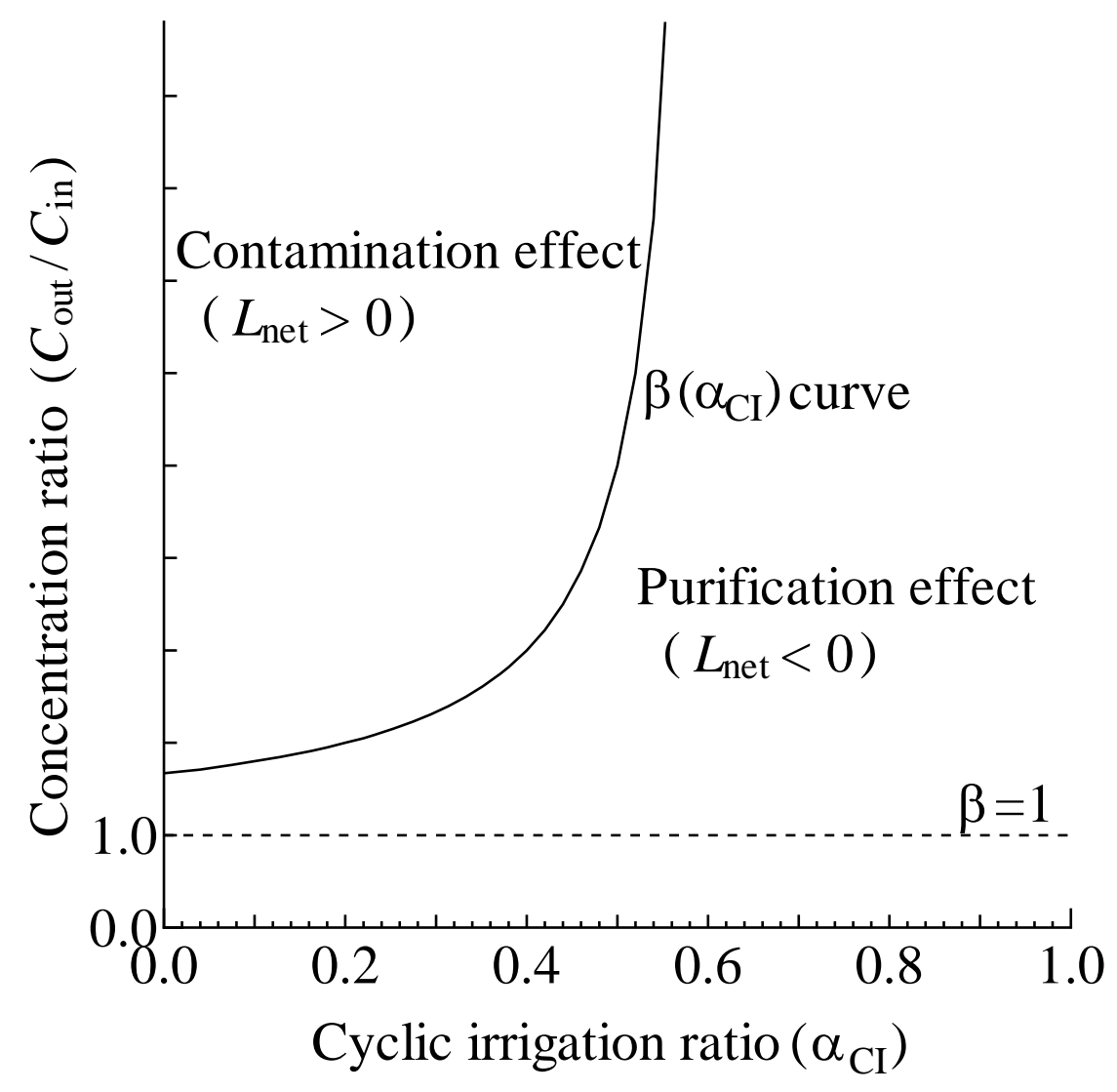




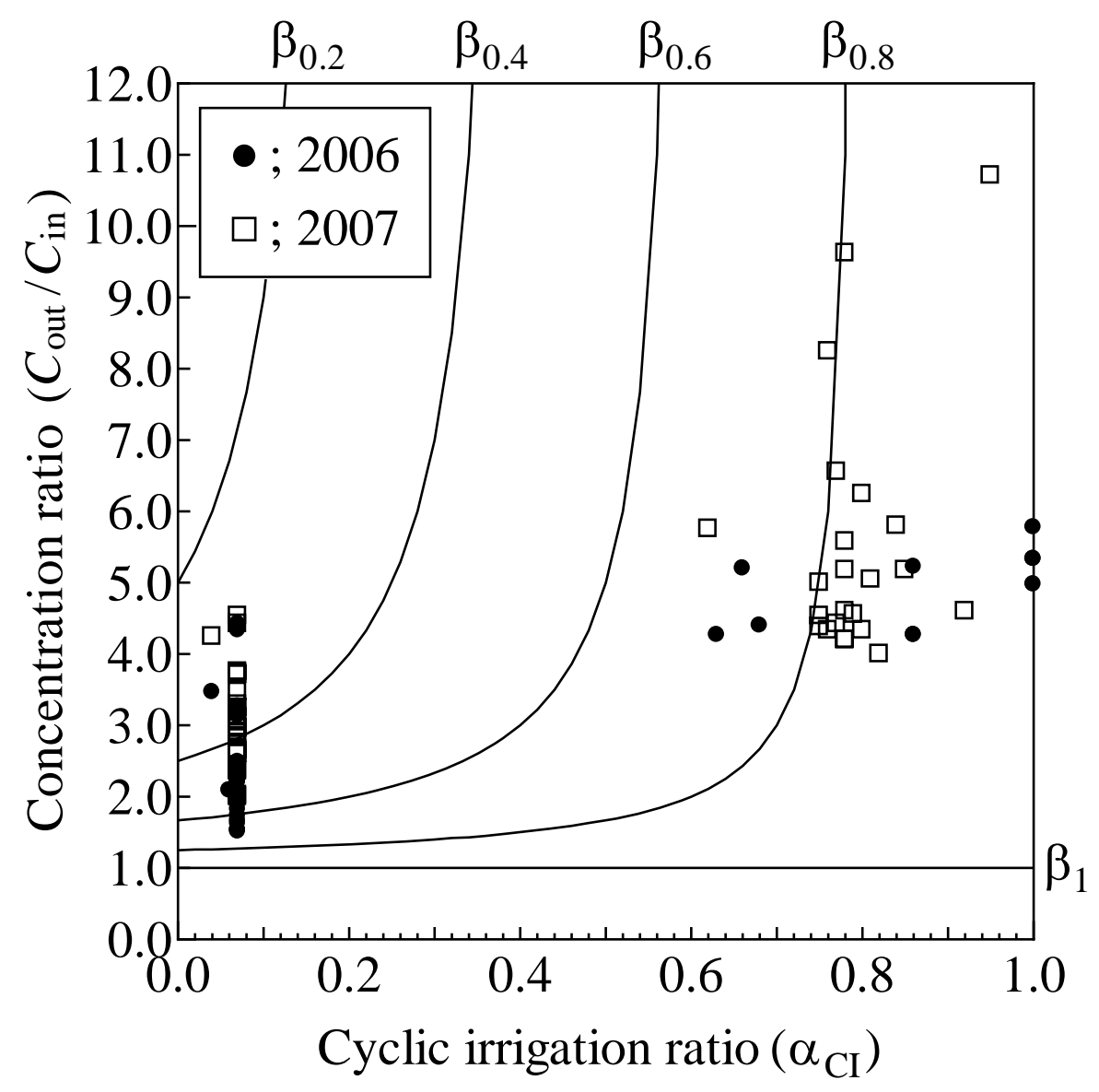

Figure 8 